\title{
ARTICLES
}

Submitted 10.13.2015. Approved 10.13.2016

Evaluated by double blind review process. Scientific Editor: Carlos L. Rodriguez

DOI: http://dx.doi.org/10.1590/So034-759020170103

\section{COMPETITIVE DYNAMICS AND EARLY MOVER ADVANTAGES UNDER ECONOMIC RECESSIONS}

\author{
Dinâmica competitiva e vantagem do pioneiro em recessões econômicas \\ Dinámica competitiva y ventajas de precursores en recesiones económicas
}

\begin{abstract}
In light of the recent macroeconomic instability in global markets, we examine the evolution of competitive dynamics and firm profitability when industries are subject to recessions. Although ordinary intuition leads most to view recessions as harmful, we highlight conditions under which they enhance the relative value of industry-level supply-side isolating mechanisms, thereby affording early movers significant and sustainable profit advantages vis-à-vis laggards. We observe that the distribution of firm size within the industry switches from a bi-modal distribution (i.e., one dominated by both small and large firms) to a right-skewed one (i.e., dominated mostly by large firms) in these contexts, thereby signaling the rise of important opportunities in the form of less rivalrous competitive contexts for survivors of recessions. We derive our results from formal modeling and multiple simulation runs. KEYWORDS | First mover advantages, industry life cycle, competitive dynamics, recessions, supply side isolating mechanisms.
\end{abstract}

\section{RESUMO}

À luz da recente instabilidade macroeconômica nos mercados globais, examinamos a evolução da dinâmica competitiva e da rentabilidade das empresas quando indústrias estão sujeitas a recessões. Embora a intuição comum leve a maioria das pessoas a enxergar as recessões como prejudiciais, destacamos condições sob as quais elas melhoram o valor de mecanismos de isolamento em nível de indústria e do lado da oferta, proporcionando aos pioneiros vantagens de lucro significativas e sustentáveis em comparação com seguidores. Observamos que a distribuição do tamanho das empresas passa de uma distribuição bimodal (ou seja, dominada tanto por empresas grandes quanto pequenas) a uma distribuição enviesada à direita (ou seja, predominantemente dominada por empresas grandes) nesses contextos, sinalizando a emergência de importantes oportunidades na forma de contextos de concorrência com menor rivalidade para os sobreviventes das recessões. Derivamos nossos resultados de execuções de modelagem formal e múltiplas simulações.

\section{ROBERTO VASSOLO}

rvassolo@iae.edu.ar

Professor at Universidad Austral,

IAE Business School - Buenos Aires, Argentina and Pontificia Universidad Católica de Chile, Facultad de

Ingeniería - Santiago, Chile

\section{JAVIER GARCÍA-SÁNCHEZ}

jgsanchez@iae.edu.ar Professor at Universidad Austral, IAE Business School - Buenos Aires, Argentina

\section{LUIZ MESQUITA}

mesquita@asu.edu

Professor at Arizona State University, School of Business - Arizona, United States of America
PALAVRAS-CHAVE / Vantagem do pioneiro, ciclo de vida de indústria, dinâmica competitiva, recessões, mecanismos de isolamento do lado da demanda.

\section{RESUMEN}

En vista de la reciente inestabilidad macroeconómica en los mercados globales, analizamos la evolución de la dinámica competitiva y rentabilidad firme cuando las industrias están sujetas a recesiones. Aunque la intuición común lleva mayormente a considerar las recesiones dañinas, enfatizamos las condiciones en las que mejoran el valor relativo de mecanismos aislantes de suministros a nivel de la industria, por lo tanto, proporcionándoles a los precursores ventajas provechosas significativas y sostenibles con respecto a los rezagados. Observamos que la distribución de tamaño firme dentro de la industria cambia de una distribución bimodal (es decir, una dominada tanto por pequeñas como por grandes empresas) a una sesgada hacia la derecha (es decir, dominada mayoritariamente por grandes empresas) en dichos contextos, por lo tanto indicando el surgimiento de importantes oportunidades en la forma de contextos menos rivales para sobrevivientes de recesiones. Derivamos nuestros resultados de modelado formal y ejecuciones de simulaciones múltiples.

PALABRAS CLAVE / Ventajas de precursores, ciclo de vida de la industria, dinámica competitiva, recesiones, mecanismos aislantes del lado de suministros. 


\section{INTRODUCTION}

What should firms do when competing in contexts subject to a high probability of macroeconomic recessions? In the past couple of decades, important markets in distinct corners of the world seem to have suffered severe economic contractions. For instance, Singapore, Korea, Hong Kong, Brazil, and Argentina collapsed during the 1990s, whereas the United States and the European Union, in turn, were severely affected in the first decade of this century. As if to show that there is some "regularity" to what most usually see as an "exception," a typical OECD country experienced approximately six recessions between 1960 and 2007 (Claessens, Kose, \& Terrones, 2009, 2010). The relevance of the matter is evident with the ubiquitousness of these exogenous threats and the lack of clear strategic imperatives for firms exposed to them (García-Sánchez, Mesquita, \& Vassolo, 2014). This phenomenon can gravely confuse seasoned top managers. The following 2001 quote from a top executive in Argentina-a country that at the time underwent an acute recession-highlights this strategic confusion: "Although Monsanto has been first to commit and dominate the local market for genetically modified seeds, headquarters has decided to not only curb but even withdraw its pledges and rethink its further investments in this market. We fear the economic turmoil may end up shifting the sources of advantages and shuffling the market positions of rivals. In fact, Wall Street has already penalized us for our large Argentine asset exposure."

Indeed, countless multinationals that had confidently entered Argentina's economic opening a decade earlier left the country not even two years into the economic recession (Carrera, Mesquita, Perkins, \& Vassolo, 2003). However, without knowing what the industry's competitive context would look like in the event of a recession, prescribing the suitability of given strategic courses is problematic. On the one hand, managers may stick to their original plans and race ahead of rivals, albeit such dedication to troubled markets can penalize firm value (as Monsanto found out). On the other hand, hesitation can give a firm valuable flexibility; however, the firm may be more vulnerable to rivals if the market flourishes.

Given today's recurrent state of economic volatility in several countries, the relevance of the matter is qualified by the matter of when and not if it will return. Motivated by this problem that currently lacks clear scholarly and practice guidelines regarding whether to enter an industry and how fast to growth in the face of a macroeconomic recession, in this paper we develop theoretical principles by examining the consequences of recessions for competitive dynamics and firm performance. To constrain our study to a manageable set of parameters, we focus on an industry with supply-side isolating mechanisms that generate first-mover advantages (FMAs) in the form of higher profits. We argue that recessions represent discontinuities that alter an industry's carrying capacity in the short run, but that induce durable and-for some firms, but certainly not for allvaluable effects along the rest of industry life.

We build on García-Sánchez, Mesquita, and Vassolo (2014) to develop a mathematical simulation model, simplifying it to focus on the mechanisms that generate FMA. Through multiple simulation runs, we observe that the distribution of firm size within the industry switches from a bi-modal distribution (i.e., one dominated by both small and large firms) to a right-skewed one (i.e., one dominated mostly by large firms) in these contexts, thereby signaling the rise of important opportunities in the form of less rivalrous competitive contexts for survivors of recessions. Therefore, although ordinary intuition can lead most to view economic shocks as harmful, we theorize on an alternative side of this phenomenon, which is that they instead create conditions that firms can strategically use to boost FMA, more specifically affording early movers valuable opportunities over laggards that do not exist in stable contexts. Therefore, the model sets the conditions for whether following a procyclical strategy (accelerating entry and growth in moments of macroeconomic expansion but under the likelihood of recessions) is optimal. The results are also relevant for multiple foreign market entry into industries subject to FMA.

Our model shows the advantages of following procyclical strategies; however, it also complements prior studies that eventually recommend anticyclical strategies (e.g., Mascarenhas \& Aaker, 1989; Greer \& Ireland, 1992; Gracias-Sanchez et al., 2014). In addition, with this study, we join a quickly growing body of literature that relates macroeconomic shocks with competitive advantages (Mascarenhas \& Aeker, 1989; Chakrabarti, Singh, \& Mahmood, 2007; Chakrabarti, Vidal, \& Mitchell, 2011; GarciaSanchez, 2014; Ghemawat, 1993; Wan \& Yiu, 2009). Using this approach, we also contribute to characterizing a contingent effect that reinforces FMA (Mascarenhas, 1992; Suarez \& Lanzolla, 2007) even in the context of foreign market entry. Lastly, we offer managers, such as the Monsanto executive, a rationale for controversial strategic decisions.

\section{BACKGROUND}

\section{FMA and the Industry Life Cycle}

First-mover advantages (FMAs), known as the rewards that accrue to those who move ahead of rivals (Lieberman \& Montgomery, 
1988), represent an important strategy concept. Previous FMA research explains that by assertively preempting laggards (e.g., entering and growing quickly) and maintaining technological leadership (e.g., investing in learning and R\&D), early movers can sustain survival, market share, and profit advantages (Mascarenhas, 1992; Suarez \& Lanzolla, 2007). In contrast, late movers often struggle to catch up and close time-dependent resource and performance disadvantages. It is well accepted that FMAs vary along the industry life cycle. Specifically, industries are known to evolve along three commonly recognized stages: an early exploratory phase, an intermediate development stage, and a mature phase. During the earliest stage of industry life, many entrants are attracted by the absence of size advantages and the promise of hefty returns for successful innovation sometime in the near future (Klepper, 1997). In this "fluid" period of development, performance criteria for new products are not well defined. As development proceeds, a particular technology design emerges dominant. Producers' know-how also evolves over time, increasing $R \& D$ investment requirements for new entrants to replicate the knowledge of incumbents. Eventually, although industrial knowhow becomes codified, decreasing R\&D entry barriers, profit margins are compressed enough to make entry unattractive. As the industry reaches maturity, competition intensifies given prior entry, thus compressing profit margins and curbing further entry. High rivalry also forces the least efficient firms to exit. At this point, competition has shifted from technology to price.

The importance of recognizing these evolutionary stages along the life of an industry lies in the changing effect on sources of competitive advantage (Baum, 1995). Passing from earlier phases to the maturity stage involves a reversal in the relative role of innovation. The earliest stage is fundamentally entrepreneurial and favorable to innovative entry, whereas maturity is the most enabling ground for established (larger) firms with well-developed operational routines (Winter 1984). In other words, rivalry among firms increases as the industry evolves and demand saturates at a fairly smooth pace, shifting the sources of competitive advantage. The evolution of profitability in this context determines the structure of the industry at maturity, with the accentuated emergence of successful large players. Specifically, the industry population tends to become more concentrated, with larger companies dominating the environment and fewer small and mid sized ones occupying niche positions. Undoubtedly, the sources of profitability differ from large companies to niche players.

The previously described regularities along the industry evolutionary trajectory enable key theoretical elements to understand the evolution of competition in macro-economically volatile contexts. On the one hand, it helps managers and scholars understand that the economy provides resources to firms in an overall pattern. However, this provision fluctuates as gross domestic product (GDP) moves from periods of expansion to periods of contraction. Failing to distinguish changes in the level of macroeconomic activity implies a strong but questionable theoretical assumption regarding selecting mechanisms being equivalent in at least two aspects: (a) that these selecting pressures will equally affect the survival likelihood of different cohorts (e.g., early versus late entrants) of firms, regardless of the type of advantages they already possess; and (b) that these selecting mechanisms are stable along the industry life cycle (e.g., emergent versus maturity phases of industry life).

Our goal is then to incorporate recessionary events in the industry life cycle subject to FMA. To do so, we next examine the evolutionary patterns of the macroeconomic environment.

\section{What are recessions?}

In every country, the level of macroeconomic activity fluctuates around a long-term trend, moving from cycles of recession-a trough point in the overall oscillatory evolution of economic growth-to expansion (Burns \& Mitchell, 1946; Claessens, Kose, \& Terrones, 2009, 2010). Recessions are particularly important moments because they affect the industry's carrying capacity and exogenously enhance its internal competitive pressures.

During recessions, aggregate demand contracts. This downturn causes further disruptions in the liquidity of exchanges of capital and goods, as measured by factor productivity and production capacity (Mendoza, 2006, p. 411). As unemployment surges and the local currency plummets, local market dwellers observe an acute decline in wage levels (Calvo \& Mendoza, 1996; Calvo, Izquierdo, \& Talvi, 2006). This sequential chain of economic events ultimately culminates in an acute decline in demand and GDP (Calvo \& Mendoza, 1996). Depending on the institutional conditions and the causes of the recession, economic activity eventually returns to pre-recession levels. However, as shown in Ayyagari, Demirgüç-Kunt, and Maksimovic, (2011), economic recovery has a strong and lasting heterogeneous effect on the competitive standing of companies. They observe that sales recovery is highly heterogeneous, with some companies increasing their sales and others decreasing theirs in the aftermath of recessions. Therefore, with economic shocks being this ubiquitous, understanding their effects on firm profitability and FMA becomes much more pressing.

Moreover, although antecedents seem to recommend a countercyclical strategic behavior (Mascarenhas \& Aaker, 1989; Greer \& Ireland, 1992; Garcia Sanchez et al., 2014), avoiding over-investments in periods during which the risk of an economic shock is growing, managers seem not to follow this advice and 
usually follow procyclical strategies (Mascarenhas \& Aaker, 1989; Ghemawat, 1993; Dobbs, Karakolev, \& Malige, 2001; Pearce \& Michael, 2006). To shed light on this conundrum, we develop a mathematical simulation model of an industry with FMA on the basis of cost competition and examine the effect of a recession on such advantages.

\section{MODEL AND SIMULATION MECHANICS}

Simulation methods are powerful approaches for theory building (Davis, Eisenhardt, \& Bingham, 2007; Harrison, Lin, Carroll, \& Carley 2007). This approach is useful when a simple theory existsthat is, when an existing theory is underdeveloped and has only a few constructs and related propositions (Davis, Eisenhardt, \& Bingham, 2007). In our case, the effect of recessions on competitive dynamics and first-mover advantages has strong theoretical underdevelopment. We follow the standard simulation procedure of formally modeling our phenomenon and deriving next theory propositions from multiple simulation runs (Harrison, Lin, \& Carroll, 2007). In rare empirical studies, scholars may choose to review prior studies and deductively distill existing hypotheses, and they compare such a prior theory with new findings from computer simulation runs (e.g., see Siggelkow \& Rivkin, 2006). However, where prior studies are incomplete in confidently generating new theoretical models, formal modeling and computer simulations help to more precisely specify causal relations given that specific processes are postulated and then directly observed in simulation runs (Cohen \& Cyert, 1965; Harrison et al., 2007). Moreover, when research depends on the occurrence of natural events (which themselves trigger a multitude of uncontrolled effects that are outside the main focus of interest in the study, but that may endogenously affect the results), simulations become particularly attractive because formal modeling permits authors to precisely establish rigorous sets of controls. In this case, simulations are used instead to derive new theoretical propositions in an inductive fashion (e.g., Miller, Zhao, \& Calantone, 2006; Siggelkow \& Rivkin, 2006).

Given that our model parameters (e.g., window period of observation, numbers of new entrants, and others) are similar, the model we develop takes its basic form from García-Sánchez et al. (2014) precisely to help contrast our distinct findings vis-à-vis a similar background. Yet, our model is a simplification of theirs because our goal is to stress the relationship between FMA and macroeconomic turbulence. In particular, our model describes a competitive dynamic process through which recessions produce a shift in industry munificence levels to increase inter-firm rivalry and change firms' performance. In turn, the simulation analyses provide numerical solutions on the basis of which we develop testable propositions on the evolution of competition (i.e., regarding average industry concentration) and firm advantages (i.e., regarding FMA in profits and survival). At the industry level then, we adapt a Cournot model and a competitive entry and exit process. The Cournot model is particularly suitable to analyze supply-side isolating mechanisms.

Every period, each firm chooses its output levels, which we aggregate into industry supply (formally, $Q_{t}=\Sigma Q_{i t}$ ). In turn, aggregate supply balances with demand and the market clears, inducing price equilibrium. Our demand curve is a standard constant elasticity (i.e., downward sloping) function with a modification to introduce a demand shift when the market suffers a recession. We also include a product substitute as a price ceiling. Formally, $P_{t}=D\left(Q_{t}\right)=\min \left(S,\left(\Delta / Q_{t}\right)^{[/ /]}\right)\left(1-\Pi_{t}\right)$, where $\mathrm{P}_{\mathrm{t}}$ is the market price in period $t$ and $\mathrm{D}($.) is the demand function. $S$ is the substitute product price, $\Delta$ is a demand parameter, $\square$ is the elasticity of demand, and $\Pi_{t}$ is the parameter to introduce recessions.

The analysis of the recession is straightforward. We simply induce a lower equilibrium price for the same quantity of output through a downward shift in the demand curve. This shift responds to the parameter $\left(1-\Pi_{t}\right)$, where $\Pi$ represents the recession magnitude and equals zero if $t$ falls outside the recession period, or $\Pi$ otherwise (García-Sánchez et al., 2014). Recessions differ in magnitude and duration. To obtain external consistency, we consider recessions of different magnitudes and at different times during the life of an industry. The model certainly permits easy adaptation for longer recessions, but for ease of exposition, we focus on short and sharp contractions and recoveries.

Regarding timing and similarly to García-Sánchez et al. (2014), we selected recessions in year eight, when the industry was undergoing strong development and growth, and in year 25 , when the industry was mature. Regarding magnitude, we imposed shocks of $8 \%$ and $10 \%$. It is worth noting that we do not distinguish between macroeconomic contraction and industry contraction. Recessions affect demand contraction for many different industries at different levels. For ease of exposition, we assume that macroeconomic contraction affects the contraction of general demand and the demand for industry products at the same level.

Following García-Sánchez et al. (2014), we assume that each player produces a single good. Further, we specify the dynamics of a firm's learning and R\&D investments that affect its capabilities and heterogeneity. Firms do not directly choose output levels but do so on the basis of their capital stock $\left(Q_{i t}=a K_{i t}\right)$ that, in turn, depends on capital expenditure (capex) decisions made every period. Such investment decisions are made to 
maximize profits in the following period. Formally, $\mathrm{K}_{i(t+1)}=\mathrm{K}_{i t}{ }^{*}(1-$ $\delta)+I_{i(t+1)}$. Here, $I_{i(t+1)}$ represents capital expenditures, which occur on the basis of profit maximization for period $(t+1)$.

Profits are defined by $\Pi_{i t}=\mathrm{P}_{t} \mathrm{Q}_{i t}-\mathrm{c}_{i t}\left(\mathrm{Q}_{i t}\right)-(\rho+\delta) \mathrm{K}_{i t}-\mathrm{r}_{i t}$, with $\pi_{i t}$ being the profit of firm $i$ in period $t$. We note that profit is a function of $c_{i t}(\cdot)$, which represents the related unit cost function. This cost function depends on accumulated learning and current technology, which is the product of past R\&D expenditures. Unit costs decline over time as a function of learning, which itself is a function of accumulated output and first unit cost. Additionally, the cost curve can shift down depending on R\&D investments. As such, R\&D affects output costs by reducing the first unit cost. Regarding learning, the first unit cost represents a given production technology. Formally, $c_{i t}\left(Q_{i t}\right)=c\left(Q_{i t}, \bar{Q}_{i t}, \tau_{i t}\right)=\tau_{i t}\left(r_{i t}, \tau_{i(t-1)}\right.$

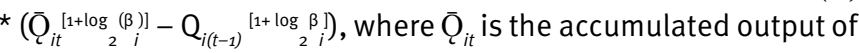
firm $i$ up to period $t, \tau_{i t}(\cdot)$ is the hypothetical first unit cost using the technology as of period $t$, and $\beta_{i}$ is the progress ratio of the learning of firm $i$. The progress ratio of learning is a constant characteristic of every individual firm, determined at the moment of entry through a random draw from a normal distribution. By concept, as cumulative output doubles, the unit cost declines by $\beta$. For instance, an $80 \%$ progress ratio means a $20 \%$ unit cost reduction each time cumulative output doubles.

Lastly, $\rho$ is the cost of capital, $\delta$ is the depreciation per unit of capital, and $r_{i t}$ is the R\&D expenditure of firm $i$ in period $t$. At the end of every period, poor performers exit. Formally, exit occurs if either performance or capital stock results are lower than their respective minima, that is, $\mathrm{K}_{\mathrm{it}} \leq \mathrm{K}^{\mathrm{min}}$ or $\mathrm{x}_{\mathrm{it}} \leq \mathrm{x}^{\mathrm{min}}$, with $\mathrm{x}_{\mathrm{it}=} \mathrm{x}_{\mathrm{i}(\mathrm{t}-1)} \theta+$ $\left(\pi_{i t} / K_{i t}\right)(1-\theta)$. In turn, performance is defined as a distribution lag function of return. On the other hand, potential new entrants are given random initial conditions if their expected performance at the prevailing price is higher than their minimum threshold.

As said above, investment decisions are based on profit maximization whose first order condition is expressed in terms of mark-up $\mu_{i t}$, defined as $\mathrm{P}_{t} / \mathrm{mc}_{i t}$ where $\mathrm{mc}_{i t}$ is the marginal cost of firm $i$ at period $t$, ie the first derivative of the total cost function. When profits are maximized the optimal mark-up fulfills $\mu_{i t}=(\varepsilon+(1-$ $\left.\left.\mathrm{s}_{i(t-1)} * \Psi\right)\right) /\left(\varepsilon+\left(1-\mathrm{s}_{i(t-1)} * \Psi-\mathrm{s}_{i(t-1)}\right)\right.$, where $\mathrm{s}_{i t}$ is firm i's market share, and $\Psi$ is the supply elasticity of the firm i's competitors as a whole, which we assume as per the Cournot conjecture, i.e., they consider the possible responses of others. If current mark-up is higher than the optimum the firm invests more than it depreciates, otherwise it stops investing and lets assets depreciate. In formal terms, $\mathrm{I}_{i t}=$ $\min \left(\Phi_{i t}, \mathrm{~K}_{i(t-1)}{ }^{*}\left(\lambda^{\star}\left(1-\mu_{i t}{ }^{*} m c_{i(t-1)} / P_{t-1}\right)+\delta\right)\right)$, where $\Phi_{i t}$ is the maximum amount of funds available for investments according financing restrictions, $\lambda$ is a model parameter that regulates the speed of growth, which represents intrinsic business restrictions, such as personnel training, asset availability, and others.
Additionally to capex decisions, firms choose the R\&D expenditure, which produces cost curve shifts. One may conceptually think of a technology innovation that does not discard previous accumulated learning. We use an asymptotic function with a random error component and a parameter $(0<\gamma \leq 1)$ that represents the R\&D skills of each firm. These R\&D skills are determined at a firm's moment of entry. Thus, $\tau_{i t}\left(r_{i t}, \tau_{i(t-1)}\right)=\tau_{i(t-}$ ${ }_{1)}^{*} /\left(\gamma_{i}^{*}\left(r_{i t}+1\right)\right)^{\star} \xi_{i t}$, where $\gamma_{i}$ is firm i's R\&D efficiency and $\xi_{i t}$ is its innovation error at period $t$. This function implies a minimum $R \& D$ investment to prevent an increase in the first unit cost $\left(r_{i}^{\text {min }}\right.$ $\left.=\left(1 / Y_{i}\right)-1\right) \cdot R \& D$ investment also reflects profit maximization for $(t+1)$. For simplicity, capital and $R \& D$ investment decisions are made sequentially (i.e., R\&D investment is decided after output has been chosen). Maximizing for $r, r_{i t}{ }^{*}=\left[\left(\tau_{i(t-1)} / \gamma_{i}\right){ }^{*}\left(\bar{Q}_{i t}{ }^{1+\log (\beta)}{ }_{i}\right)-\right.$ $\left.\left.\bar{Q}_{i(t-1)}{ }_{2}^{1+\log (\beta)}\right)\right]^{(1 / 2)}-1$, where investments will be made if $r_{i t}{ }^{*}>r_{i t}{ }^{\text {min }}$. As is the case with capex, R\&D expenditures are capped by funds availability, such that $r_{i t}^{\max }=\Phi_{i t}-I_{i(t-1)}$. In other words, $r_{i t}=\max \left(r_{i}^{\min }\right.$, $\left.\min \left(r_{i t}{ }^{*}, r_{i t}{ }^{\max }\right)\right)$.

Entry is a critical aspect in any model, and in our case, it is a random variable. The number of potential entrants is a percentage of the number of firms in the industry that determines the pool; this percentage is taken from a normal distribution with mean and standard deviation parameters of the simulation. Parameters for new entrants are randomly assigned. Entry occurs if performance at the current price is higher than $x^{\min }$.

Each run of our simulation produces a particular evolutionary path, whereas our final analysis is based on the average of 1,000 runs. We calibrated initial parameters (Table 1) found in the related literature (e.g., Winter, 1984; Calvo et al., 2006; García-Sánchez et al., 2014). We ran our simulations using the Repast Simphony software platform (Repast, 2016).

\section{SIMULATION RESULTS AND THEORETICAL CONSIDERATIONS}

Similar to prior simulation studies, we begin by demonstrating a base industry evolution path (Graph 1)-that is, a simulation run highlighting development and maturity phases, interspersed by an industry shakeout-that shows the number of firms (left y-axis) and industry output (right y-axis), along the life of an industry (in years, $x$-axis). Note that this description does not include the early exploratory stage of the industry, a common practice in prior empirical studies on which we base our own (e.g., Klepper \& Graddy, 1990; García-Sánchez et al., 2014) because it represents a searching stage more than a competition phenomenon and its inclusion involves non-trivial mathematical challenges. The results indicate that the industry evolves as a prototypical case 
(Klepper \& Graddy, 1990; Klepper, 1997; Agarwal, Sarkar, \& Echambadi, 2002).

Table 1. Simulation parameters

\begin{tabular}{|c|c|}
\hline Name & Value \\
\hline Price of substitute & 3 \\
\hline Demand elasticity & 1 \\
\hline Demand parameter & 800 \\
\hline Supply elasticity & 2 \\
\hline Investment parameter & 0.5 \\
\hline Initial capital mean & 4 \\
\hline Initial capital StdDev & 0.1 \\
\hline Minimum capital & 1 \\
\hline Max external borrowing & 0.3 \\
\hline Performance weight & 0.6 \\
\hline Minimum performance & -0.02 \\
\hline Cost of capital & 0.15 \\
\hline Capital productivity (A) & 1 \\
\hline Depreciation & 0.1 \\
\hline Entrants mean & 12 \\
\hline Entrants StdDev & 0.1 \\
\hline Fixed cost & 0.5 \\
\hline R\&D efficiency mean & 0.9 \\
\hline R\&D efficiency StdDev & 0.1 \\
\hline Initial first unit cost & 2 \\
\hline Learning rate mean & 0.9 \\
\hline Learning rate StdDev & 0.1 \\
\hline Sudden stop magnitude & $8 \% ; 10 \%$ \\
\hline Sudden stop duration & 1 \\
\hline Sudden stop start & $8 ; 25$ \\
\hline
\end{tabular}

Industry variance emerges from the stochastic nature of the different parameters. Therefore, the aggregate level of industry growth is contingent on individual firms' entry and growth decisions. We report the aggregate results of the 1,000 simulation runs, which hide part of this variability.

In the following sections, we analyze the effect of recessions on industry evolution and competitive advantages. For this purpose, we first study the effect of recessions on the distribution of firm size within the industry. We take this approach because size is a fundamental antecedent of firm survival and growth, and indicates potential sources of competitive advantages (Baum, 1995; Dobrev \& Carrol, 2003; Porter, 1985; Josefy, Kuban, Ireland, \& Hitt, 2015). A change in the structure of the size distribution is a necessary condition for detecting that recessions alter the value of the isolating mechanisms.

\section{Recessions and firm size distribution}

To examine the evolution of the size distribution, we contrast the size profile of firms in industries subject to recessionary events vis-à-vis those free of them. Graph 2 shows a simulated snapshot in year 50 of an industry that hypothetically evolved from the same birth year (year 1) in three different and independent macroeconomic environments. In each of these environments, the industry similarly goes through the same natural development phases (namely, development, shakeout, and maturity), except that each was subject to different recessions. In the "base model," environment 1 was stable for the 50 years during which the industry evolved. In contrast, environments 2 and 3 were respectively hit in years 8 and 25 by recessions of similar magnitude. The selection of these two moments has theoretical motives: they allow us to examine the effect of the recession with different conditions of environmental munificence in key moments during the life of the industry. Therefore, although we only analyze one type of industry, we highlight different levels of munificence, expanding the generalizability of the results. We believe that a snapshot analysis of average firm size in year 50 accurately reflects what we would find in the long run.

To contrast the firm size profile across these three hypothetical industries, we classified all firms by the size of their output in year 50 across 10 different categories evenly distributed in terms of number of competitors. Each group of three columns in Graph 3 then represents the count of firms in that size category, by context. The smallest firms conform to the first category, represented in the first group of vertical columns from left to right along the $x$-axis (i.e., the group closest to the $y$-axis). Following the same logic, our 10 categories are thus displayed sequentially from left to right, given that the last category (the one farthest to the right along the $x$-axis) incorporates all firms producing more than 182 units of output in year 50 .

The first aspect to highlight is the size profile of firms in the base industry (i.e., brick-patterned columns). This base industry represents the natural size distribution of firms and results from our choice of model parameters of learning, R\&D investments, and entry and exit decisions in a context not subject to recessions. This distribution is skewed toward the left, meaning that the population has a vast majority of smaller players despite many large firms dominating the market. In contrast, the size profile of 
firms in the industry subject to a recession in year 25 (i.e., fullpatterned columns) differs significantly. The size distribution is skewed to the right, indicating a concentrated industry populated by large firms. The results for the smaller recession effect (i.e., dot-patterned bars) are not as starkly dissimilar from that of the recession-free context but are still different. However, the earlier in the life of an industry that recessions occur, the quicker the industry recovers.

In this analysis, we highlight the different strategic approaches by firms across different environments. Firms subject to recessions, assuming they survive over the long haul, are likely to enjoy more oligopolistic and profitable contexts, whereas their counterparts in recession-free settings are more likely to suffer a more rivalrous context at a much later stage in the life of an industry. The point is that recessions induce a higher concentration of the industry population, with few medium-sized and even fewer small-sized companies in the market.

P1a: Recessions that occur momentarily along the industry life cycle permanently alter the long-term size distribution of the population.

P1b: In a context of FMAs that emerge from supply-side isolating mechanisms, recessions shift the industry structure; that is, compared with that of a recession-free context, an industry comes to display a population size distribution dominated by larger firms.

\section{Graph 1. Base evolution of number of firms (left-hand side Y-axis) and industry output (right-hand side Y-axis)}

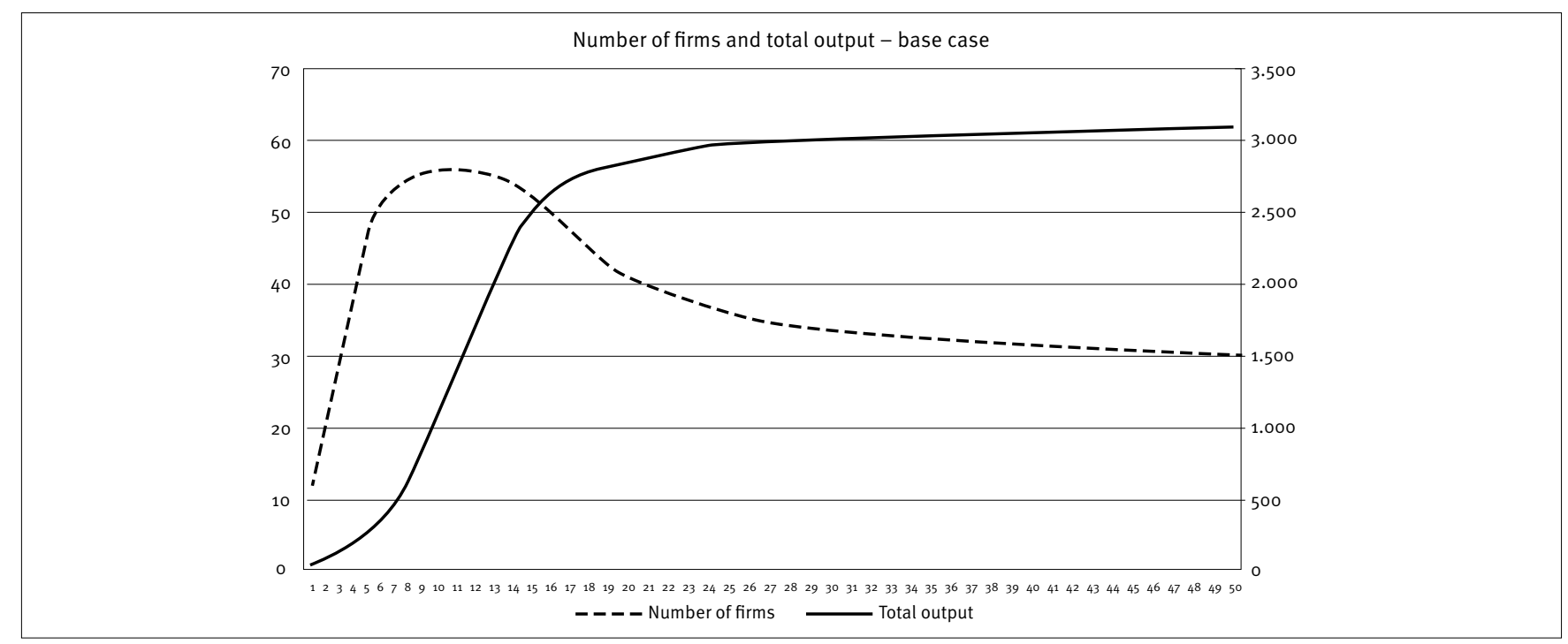

Graph 2. Evolution of size profile under recession on different moments

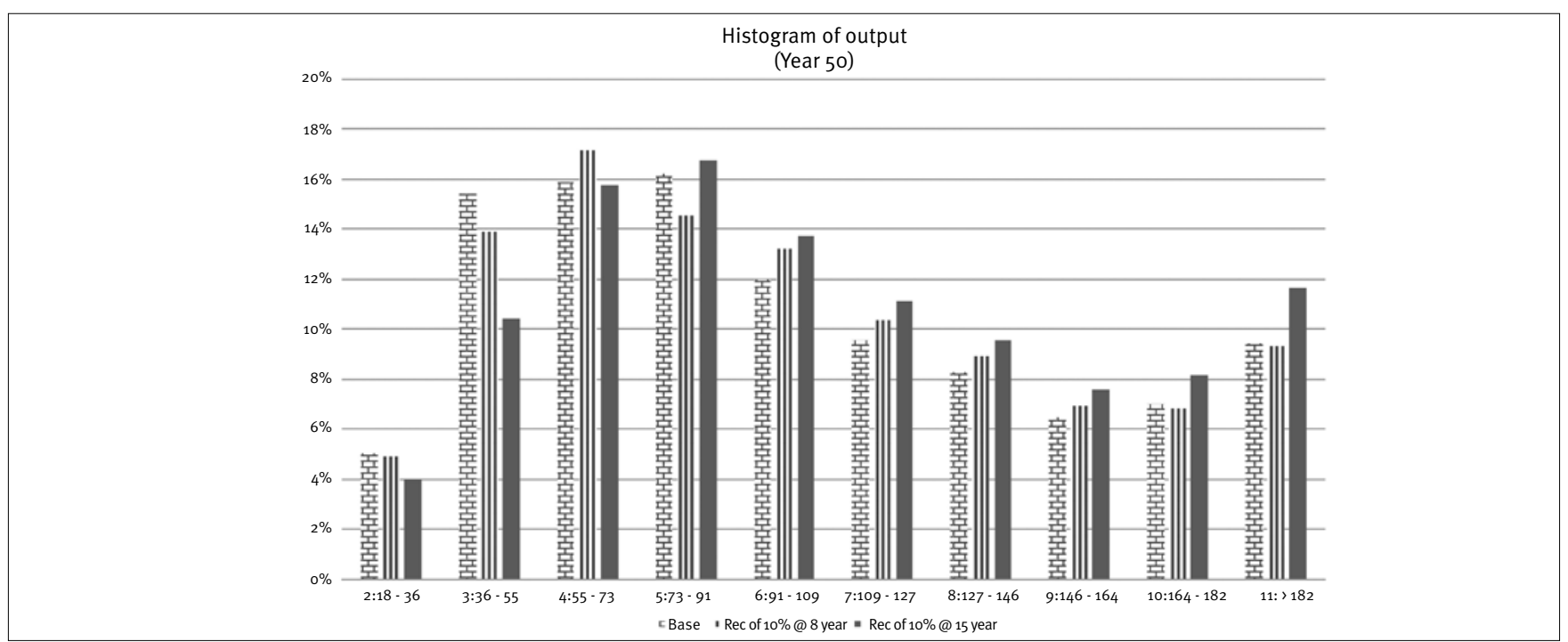




\section{Small competitors survival}

We have observed that recessions reinforce large competitors' advantages. It is worth asking whether small competitors that survive are latter entrants that never grow enough given a lack of resources or, rather, are niche players with sustainable competitive protection. To analyze this tradeoff, we examine the average entry year of niche players. Table 2 reports the average age of the competitors for each size.

Table 2. Age by Cohort in year 50

\begin{tabular}{|c|c|c|c|c|c|c|c|}
\hline Bucket & FirmBucketName & $\begin{array}{c}\text { Escenario } \\
\text { base } \\
\text { age average }\end{array}$ & $\begin{array}{c}\text { Valores } \\
\text { number of } \\
\text { firms }\end{array}$ & $\begin{array}{c}\text { Rec of } 10 \% @ \\
8 \text { year } \\
\text { age average }\end{array}$ & $\begin{array}{l}\text { Number of } \\
\text { firms }\end{array}$ & $\begin{array}{c}\text { Rec of } 10 \% @ \\
25 \text { year } \\
\text { age average }\end{array}$ & $\begin{array}{c}\text { Number of } \\
\text { firms }\end{array}$ \\
\hline 2 & $18-36$ & $44 \cdot 5$ & 1.6 & 44.6 & 1.5 & 44.1 & 1.1 \\
\hline 3 & $36-55$ & 46.0 & 4.7 & 46.0 & 4.2 & $45 \cdot 5$ & 3.0 \\
\hline 4 & $55-73$ & 47.0 & 4.9 & 47.1 & 5.2 & 46.8 & 4.4 \\
\hline 5 & $73-91$ & $47 \cdot 5$ & $4 \cdot 9$ & 47.5 & 4.4 & 47.5 & 4.7 \\
\hline 6 & $91-109$ & 47.9 & 3.6 & 48.0 & 4.0 & 47.9 & 3.8 \\
\hline 7 & $109-127$ & 48.1 & 2.9 & 48.1 & 3.1 & 48.1 & 3.0 \\
\hline 8 & $127-146$ & 48.3 & 2.5 & 48.3 & 2.6 & 48.2 & 2.6 \\
\hline 9 & $146-164$ & 48.4 & 1.9 & 48.4 & 2.1 & 48.5 & 2.1 \\
\hline 10 & $164-182$ & 48.5 & 2.1 & 48.5 & 2.0 & 48.5 & 2.2 \\
\hline 11 & $>182$ & 48.8 & 2.8 & 48.8 & 2.7 & 48.8 & 3.1 \\
\hline
\end{tabular}

The result shown in Table 2 indicates that larger competitors are older firms with an average age of 48.8 years. Smaller competitors are younger, with an average age of 44.5 years. It is worth noting that even small competitors entered the industry at a very early stage. Therefore, this phenomenon seems to confirm that small competitors have a sustainable niche position and that this niche decreases in size given the longterm effect of recessions on large competitors' cost structures. As the industry becomes more concentrated, larger competitors reduce the remaining space for niche players. Interestingly, the differences in age between large and small competitors are relatively small, indicating that most survivors enter the industry during the development stage. Therefore,

P2: In a context of FMAs that emerge from supply-side isolating mechanisms, recessions reduce the viability of a niche strategy.

\section{Recessions and firm profitability}

We detected that recessions generate long-term changes in industry structure (i.e., they make industries more concentrated). In addition, we detected the existence of mechanisms that allow for the existence of small firms and how these firms are affected by recessions. From here, it is imperative that we establish an association of these shifts in industry profile and firm behavior with firm-level competitive advantages. For this, we now turn to an analysis of the sources of such advantages and how recessions alter the value of isolating mechanisms. We first analyze the transitory and permanent effects on the cost structures of firms and only then analyze profitability. Graph 3 plots the evolution of the average cost for the younger and older cohorts during the maturity stage. It describes the base case and the evolution of an industry affected by a 10\% recession in year 25 . 
Graph 3. Evolution of average cost per Cohort

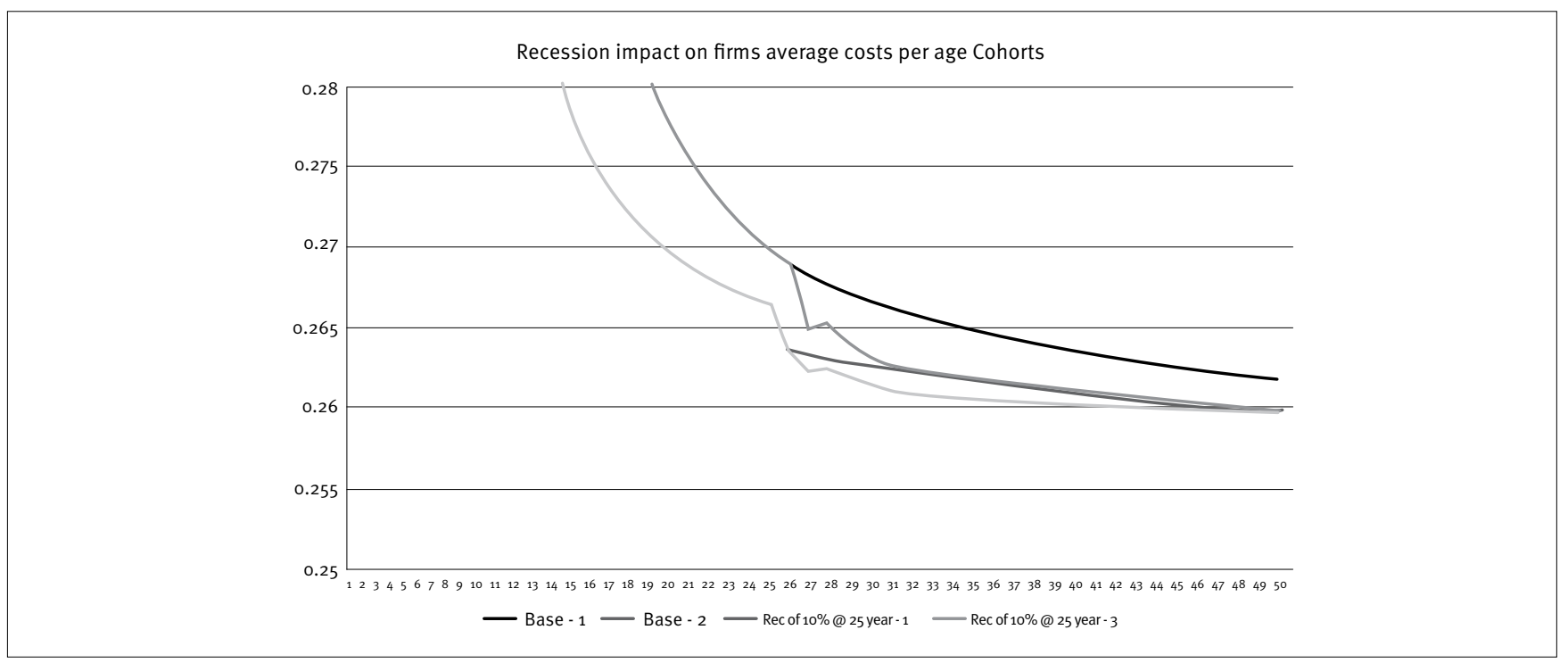

In the base case, average costs monotonically decrease for both early and late entrants. The main difference is the cost magnitude, where early movers have a clear cost advantage that persists through the years. Recessions transitorily alter this evolutionary path, inducing a sharp cost reduction. In the aftermath of recessions, the average cost increases and continues the decreasing trajectory but at a lower level than the base recession-free case.

To further examine the mechanisms behind these trajectories, Table 3 summarizes the changes in cost, quantities, profits, performance, number of competitors, and prices of each cohort for recessions of $10 \%$ magnitude that occur in years 8 and 25. To describe the short-term mechanisms, the upper left table provides these values for year 23 and the upper right table provides these values for year 27. Similarly, the lower left table provides these values for year 6 and the lower right table for year 10.

Several mechanisms are in place. First, consistent with our previous discussion, the late entrant cohort suffered the most severe reduction during recessions, although early entrants are also partially affected by recessions. In addition, an industry subject to a recession-in contrast to one that is notobserves a short-run drastic decline in average profitability. At a surface level, the logic is straightforward: because a recession constrains aggregate consumer budgets, the downshift in GDP and the associated decline in aggregate demand cause a rift vis-à-vis industry supply, thus creating a sudden and major decline in prices. This decline in market prices naturally induces an immediate and acute decline in firm profitability. In our model, firms are assumed to work at full capacity. With the new price equilibrium, competition evolves on the basis of cost effectiveness-i.e., superior production process know-how or technologies-for which cost-effective firms have an upper hand and earn market share as lower industry carrying capacity shakes out cost-ineffective firms. In summary, one obvious observation is that, during recessions, early movers have a significant surviving benefit, although average profitability in the industry falls precipitously in the very short run.

Although this short-term effect may be rather intuitive, further observations reveal a counter-intuitive result. In the aftermath of recessions, first movers attain a significant profit advantage over their counterparts in recession-free industries. However, perhaps much more importantly, such an advantage is sustainable over time.

With recessions, two aspects change significantly, thereby resulting in a profit curve that stabilizes higher than the competitive level. First, in the recovery period, demand naturally crawls back to previous levels. Given constrained industry supply (i.e., fewer players, each with production capacity capped at pre-recession levels), this demand adjustment induces a new short-term price equilibrium that is higher than competitive levels. This concentrated and highly profitable environment entices players to recalibrate their Cournot output plans. In addition, the higher concentration that results from path-dependent barriers to entry (scale and learning economies attributable to R\&D and learning-by-doing) further implies continued higher expected optimum margins in subsequent periods. Such investment decisions then repeat periodically until industry output levels reach the desired Cournot equilibrium envisaged by incumbents (i.e., until margins decline to optimum levels). 
Table 3. Profits, variable costs, and production by Cohort

\begin{tabular}{|c|c|c|c|c|}
\hline \multirow[t]{4}{*}{ tick } & 23 & & & \\
\hline & Base & \multicolumn{3}{|c|}{ Rec of $10 \% @ 25$ year } \\
\hline & 1 & 3 & 1 & 3 \\
\hline & $0-20$ & $>21$ & $0-20$ & $>21$ \\
\hline AvgCost & 0.27 & 0.27 & 0.27 & 0.27 \\
\hline Output & 40.97 & 102.19 & 40.97 & 102.19 \\
\hline Profit & -0.06 & 0.27 & -0.06 & 0.27 \\
\hline Return & $-0.37 \%$ & $-0.03 \%$ & $-0.37 \%$ & $-0.03 \%$ \\
\hline \# Firms & 7.77 & 22.46 & 7.77 & 22.46 \\
\hline Price & 0.27 & 0.27 & 0.27 & 0.27 \\
\hline
\end{tabular}

\begin{tabular}{|c|c|c|c|c|}
\hline \multirow[t]{4}{*}{ tick } & 6 & & & \\
\hline & Base & \multicolumn{3}{|c|}{ Rec of 10\% @ 8 year } \\
\hline & 1 & 3 & 1 & 3 \\
\hline & $0-2$ & $>4$ & $0-2$ & $>4$ \\
\hline AvgCost & 0.77 & 0.39 & 0.77 & 0.39 \\
\hline Output & 4.44 & 16.90 & $4 \cdot 44$ & 16.90 \\
\hline Profit & 2.41 & 14.77 & 2.41 & 14.77 \\
\hline Return & $45.67 \%$ & $83.49 \%$ & $45.67 \%$ & $83.49 \%$ \\
\hline \# Firms & $7 \cdot 31$ & 23.82 & $7 \cdot 31$ & 23.82 \\
\hline Price & 1.23 & 1.23 & 1.23 & 1.23 \\
\hline
\end{tabular}

Note: Tables per age Cohort.

Two important matters regarding capex must be noted. First, they result from early movers being more profitable given that the price stabilizes higher than competitive levels. We then highlight the fact that first movers have a significant profit advantage over their counterparts in contexts not subject to recessions. Assuming path-dependent processes, early movers accrue production process competencies over laggards and subsequently attain superior profitability. We note that first movers (i.e., firms representing the first cohort, in line above all others) have a natural profitability advantage over late movers. This by itself is consistent with earlier FMA literature (e.g., Lieberman \& Montgomery, 1988). In contrast, and less intuitively, recessions asymmetrically affect different cohorts, given that first movers turn out to be even more profitable than late movers.

\begin{tabular}{c|c|c|c|c}
\hline \multirow{2}{*}{ tick } & \multicolumn{2}{|c}{27} & \multicolumn{3}{|c}{ Rec of 10\% @ 25 year } \\
\cline { 2 - 5 } & Base & \multicolumn{2}{c}{1} & 3 \\
\cline { 2 - 5 } & 1 & 3 & $0-24$ & $>26$ \\
\cline { 2 - 5 } & $0-24$ & $>26$ & 0.26 & 0.26 \\
\hline AvgCost & 0.27 & 0.26 & 50.52 & 130.72 \\
\hline Output & 45.54 & 125.55 & 1.24 & 3.50 \\
\hline Profit & -0.10 & 0.26 & $2.28 \%$ & $2.49 \%$ \\
\hline Return & $-0.40 \%$ & $0.01 \%$ & 5.75 & 11.01 \\
\hline \# Firms & 7.35 & 11.66 & 0.29 & 0.29 \\
\hline Price & 0.26 & 0.26 & & \\
\hline
\end{tabular}

\begin{tabular}{|c|c|c|c|c|}
\hline \multirow[t]{4}{*}{ tick } & 10 & & & \\
\hline & Base & \multicolumn{3}{|c|}{ Rec of 10\% @ 8 year } \\
\hline & 1 & 3 & 1 & 3 \\
\hline & $0-6$ & $>8$ & $0-6$ & $>8$ \\
\hline AvgCost & 0.35 & 0.29 & 0.35 & 0.30 \\
\hline Output & 12.57 & 50.42 & 12.01 & 49.70 \\
\hline Profit & 1.30 & 7.59 & 1.33 & 7.92 \\
\hline Return & $9.20 \%$ & $14.38 \%$ & $9.67 \%$ & $15.18 \%$ \\
\hline \# Firms & 8.31 & 23.82 & 8.22 & 23.82 \\
\hline Price & 0.44 & 0.44 & 0.45 & 0.45 \\
\hline
\end{tabular}

In addition, the decline and rise of returns are asymmetrical. The critical element of this asymmetrical behavior is the existence of companies that exit the industry. Therefore, although macroeconomic recovery at the aggregate level is at the same level as the contraction (i.e., it was modeled with symmetrical behavior), the competitive effects are heterogeneous. In fact, as first movers grow larger from their capex investments, they further enhance their scale and cost competencies. These competencies then reinforce the entry barriers in the aftermath of recessions. In summary,

$P_{3}$ : In an industry subject to FMA built on supply-side isolating mechanisms, the existence of recessions increases early mover advantages. 


\section{Procyclical versus anticyclical strategies}

The business cycle imposes tensions on growth strategies because scale eventually puts companies in a vulnerable position when demand diminishes. Companies need to determine whether it is better to accelerate as economic activity increases and to retrench when it slows down (i.e., follow a procyclical strategy) or, eventually, to restrict growth in periods of expansion and accelerate growth during recessions (i.e., follow an anticyclical, also known as contrarian, strategy). For example, García-Sánchez et al. (2014) focus on the tension between the need to achieve FMA and the financial risk that gaining such advantage using debt imposes during recessionary times. Greer and Ireland (1992) analyze the same tradeoff in hiring processes. They examine how countercyclical hiring could ensure firms the supply of talent that is quite difficult to access during expansionary periods.

The underlying question is whether it is convenient for a firm to follow a countercyclical or contrarian strategy, taking advantage of recessions, or a procyclical strategy. In their seminal manuscript, Mascarenhas and Aaker (1989) examine these situations and assess that the answer lies in the link between a contemporaneous strategy and inter-temporal relationships, which ultimately determines the optimal strategy over the business cycle. In fact, the best strategies for recessionary or recovery periods are not necessarily the best from a long-term, inter-temporal consideration.

In our model, the main mechanisms leading to a competitive advantage work in a procyclical manner. Recessions affect every competitor in the industry; however, smaller competitors with lower cost advantages are the most affected during periods of lower industry carrying capacity and are selected out. Therefore, the best strategy is to seek cost advantages faster than other competitors, which is achieved by entering earlier and growing faster when economic activity is increasing. That is, because our model does not contain any important inter-temporal tradeoffs, the winner strategy is to behave procyclically. Consequently,

$\mathrm{P}_{4}$ : The value of a countercyclical strategy in an industry with FMA based on a supply-side isolating mechanism depends on the magnitude of the inter-temporal tradeoffs. Because the inter-temporal tradeoffs are not important, following a procyclical strategy seems superior to following an anticyclical strategy.

\section{Implications for international entry timing management}

The previous analysis allows us to develop conjectures on the effect of recessions regarding the best moment to enter a given market. However, it is not possible to expand these conclusions to foreign market entry because differences in the social, economic, and political environments affect the diffusion of a new product (Isobe, Makino, \& Montgomery, 2000). Because new products' international diffusion is slow and incomplete, the timing of entry is a source of a competitive advantage under certain conditions (Mascarenhas, 1992, 1997). In particular, international entry accelerates as uncertainty diminishes, markets mature, and/or markets are larger.

In our analysis, moving first and growing fast is a clear source of competitive advantages. Therefore, it is worth questioning the extent to which the observed delay in the international expansion of industries subject to FMA is a convenient strategy, moreover given certain hypotheses suggesting that global industry leaders are often first movers (Porter, 1986). In particular, the main supply-side isolating mechanisms emerge from scale and learning economies that are reinforced after unexpected market contractions.

In addition, to prepare for recessions (e.g., strategically choose a market position that is most beneficial under such circumstances), firms can seek to act in multiple and not perfectly correlated markets (Pearce \& Michael, 2006). Competing in different markets allows firms to diminish their exposure to recessions, even in the case of the existence of market structures that favor FMA under recessions. Recessions often lead to financial market contractions that might eventually damage a firm's growth strategy. Competing in multiple international markets that are not subject to simultaneous recessions (e.g., operating subsidiaries in Argentina, the United States, and China) enhances the possibility of financing growth strategies that seek FMA.

The main question refers to the existence of potential diseconomies that might emerge from coordinating multiple international business activities. That is, being present in multiple countries implies clear organizational costs that might generate cost diseconomies. Under the assumption that firms have such capabilities, our conjecture for fast foreign entry remains unaltered, and even more so in the context of high macroeconomic volatility. Therefore,

$P_{5}$ : In industries subject to supply-side isolating mechanisms, recessions enhance the value of entering first in foreign markets.

\section{Robustness checks}

To check for the robustness of the results, we run several alternative simulations not reported herein but that are available on request. Such alternative simulations include recessionary scenarios of different magnitudes and timings. The outcomes of these runs are 
coincident with the results previously exposed. Based on these alternative models, a particular outcome that we add to these discussions regards recessions of large magnitudes that occur in maturity. Apart from considering different scenarios, we analyze runs with different values for the most important parameters: Price of Substitute, (S); Demand Elasticity, $(\varepsilon)$; Demand Parameter $(\triangle)$; Supply Elasticity $(\Psi)$; First Unit Cost Mean $(\tau)$; Progress Ratio Mean ( $\beta$ ); Speed of Growth $(\lambda)$; Initial Capital Mean (K); Capital Productivity (a); Entrants Mean; R\&D Efficiency Mean ( $\gamma$ ); and Sudden Stop Duration. For each parameter, we attempt several neighboring values, keeping others constant. Each trial consists of at least five scenarios (i.e., base industry and four different recession levels) with 100 runs per scenario. In all cases, the results are essentially the same.

\section{DISCUSSION AND CONTRIBUTIONS}

The effect of recessions on the competitive landscape and on the competitive advantage of firms has often been overlooked by strategic management research, with a few noteworthy exceptions. For instance, the 1997 Asian crises spurred important studies that explored the relationship between macroeconomic shocks and diversification (e.g., Chakrabarti et al., 2007; Wan and Yiu, 2009; Chakrabarti, 2014). More recently, these studies were expanded conceptually to encompass not specific but more generic country settings under the influence of recessions (García-Sánchez et al., 2014). We build on this prior literature and model the evolution of industry structure (particularly as it relates to firm size-distribution), firm behavior (especially regarding the growth limitations of small firms), and the accompanying profitability of firms when industries are hit by recessions throughout their lives. We start with the observation that recessions induce otherwise unexpected shakeouts; however, beyond this obvious occurrence, we examine that such an event asymmetrically affects early and late movers, inducing sustainable FMA in the form of asymmetric survival between larger and smaller firms and profits for early movers, and shapes the industrial context to be more concentrated and less rivalrous later in the life of an industry. Specifically, the shocks tend to weed out late movers because-given path-dependent learning processes and $R \& D$ related to production processes-these firms tend to lag behind in competitive cost-based races. By staying ahead of the learning curve on production process efficiencies as well as preempting more scale-efficient production capacity spaces, first movers tend to survive recessions and, as such, naturally accrue profit advantages. However, more importantly, in the aftermath of recessions, early movers further accrue barriers to entry that congeal their concentrated market just as demand naturally crawls back to normal. As a result, in contrast to their counterparts in recession-free contexts, first movers in an industry subject to recessions will be able to enjoy significant competitive advantages long after the effects of the economic shock disappear. Lastly, first-mover advantages are more likely to be sustainable if recessions occur late rather than early in the life of an industry. This competitive dynamic process induces population evolutionary processes that favor large firms in enhancing their competitive advantages but are more detrimental to smaller firms. Said differently, recessions induce shifts in the industrial context that much more emphatically favor scale-based sources of advantage.

Certainly, because early movers naturally seem to obtain advantages throughout the life of an industry (e.g., Agarwal et al., 2002), our finding that FMA evolves larger during the life of an industry is consistent with this literature. However, we highlight that the FMA modeled and simulated in this study exists beyond those naturally arising from the resolution of endogenous uncertainties inherent in the life cycle process. Specifically, we add an important stratum of uncertainty to the analysis and, in the process, are able to ascertain how FMA evolves in contexts in which managers usually find it puzzling and complex to make decisions, such as markets undergoing recessions. This result helps us support the claim that, even in the context of foreign entry into turbulent macroeconomic environments, the early mover strategy is convenient.

It is worth noting that this analysis is valid in the absence of inter-temporal tradeoffs. García-Sánchez et al. (2014) build their mechanisms on an eventual inter-temporal tradeoff that imposes a risk to the growing speed of early movers. Under this tradeoff, our conclusions should be taken with caution. We claim that, in the absence of a clear inter-temporal tradeoff, following a procyclical strategy (i.e., reinforcing early entrance) is the best choice. However, exit is a fundamental system mechanism that determines future survivors' performance. Consequently, if being an early mover increases any size liability attributable to the existence of inter-temporal tradeoffs, following a more countercyclical strategy might be better.

Interestingly, in the presence of FMA and potential recessions, our recommendation for firms expanding internationally is to accelerate this process even under the risk of recessions. To make this claim, we assume the absence of coordination costs under multiple entries. Specifically, it may then make more sense for some-but obviously not for allto commit and make capex outlays during periods of growing macroeconomic, but only in cases in which such investments help a given firm secure its production process and cost leadership in a competitive context. 
Our modeling helps unravel factors influencing competitive dynamics and firm advantages through an ex post analysis of recessions that occur during the life of an industry. Certainly, we do not wish to advise firms with "catch-all" statements, such as "be sure to rush ahead with investments when macroeconomic uncertainty grows," but we believe that our theorizing and findings are valuable to help improve the quality of management decision making exante. As the Monsanto executive highlights, economic shocks can be very puzzling even for seasoned executives and firms leading the industry (as Monsanto did at the time). A vast majority would use common intuition to infer that recessions spell doom and subsequently adopt a "wait-and-see"' or even an "abandon the ship" strategic approach (as Wall Street suggested that Monsanto and many other firms should do in Argentina in 2001). In contrast, some wiser ones would attempt to find opportunities in the storm, as the old Chinese dictum suggests. Giving veracity to the latter's belief, we pinpoint specific sources of advantage in such troubled contexts. We highlight that a macroeconomic shock increases the value of isolating mechanisms (learning as well as preemption), thus making it worthwhile for some to "weather the storm."

Our study highlights the increase of FMAs in a macroeconomically unstable context. First movers, understood as those that significantly occupy a new market space ahead of others (Lieberman \& Montgomery, 1988), often seek the vast profits and market power rewarded to initiators. However, controversy exists as to the persistence of such advantages visà-vis quick followers. Recent research has indicated that FMAs change over time and technological and market uncertainties decrease during the life of an industry (Suarez \& Lanzolla, 2007). We build up from this point to examine how industry-level factors (i.e., number of firms) as well as firm-level advantages (i.e., profit benefits) evolve when such natural industry evolution is hit by economic shocks at different moments. The contrast is mostly apparent in that traditional life cycle concepts consider the evolution of technological and market uncertainties as inherently endogenous to the evolutionary path. In turn, our analysis considers the resulting consequences from the exogenous shocks applied to this process. The difference in the analysis is not trivial because, although FMA has attracted significant attention in the literature, much is still to be found regarding early movers' timing and subsequent access to markets and resources (Lieberman \& Montgomery, 1998, p. 1112; Suarez \& Lanzola, 2007, p. 378). Because our modeling and simulation provide a contrast between regular and recession-stricken evolutionary industry paths, our results draw attention to the increase that first-mover advantages accrue to pioneers, in addition to those already demonstrated in the prior literature.

\section{FUTURE RESEARCH AND CONCLUDING REMARKS}

Because of the limited space in a research manuscript, our study certainly faces scope tradeoffs but also points to valuable opportunities for future research. Our focus is on understanding the evolution of competitive dynamics and first-mover advantages when maturing industry contexts are hit by economic shocks. Thus, we began our model by suppressing the industry endogenous uncertainties related to Schumpeterian shocks, that is, those surrounding the competition through product technology introductions early in the life of an industry. Therefore, future modeling is needed to unveil the competitive dynamics that occur when both endogenous and exogenous uncertainties clash. One possible study is to examine how exogenous shocks disrupt network externalities that develop among sellers and buyers when product innovation evolves into an industry standard early in the Schumpeterian competition process. Further, we limited our modeling and analyses to two "supply side" forms of isolating mechanisms. Further studies need to ascertain "demand side" isolating mechanisms, such as buyer switching costs.

Two assumptions underlying our model may also be revised in future research. For one, our model is limited to a demand shock on normal goods for which price elasticity is positive. However, some industries operate with inferior goods for which demand shocks may behave differently and even in opposite ways. Thus, such differences may lead to alternative strategy implications vis-à-vis those found in this study. Moreover, we assume that production technologies developed by different firms during the life of an industry afford similar levels of organizational flexibility. Thus, shakeout occurrences tend to naturally weed out inefficient firms, which tend to be late movers in a path-dependent context in which technologies evolve linearly. However, if we allow for different levels of flexibility, a late mover with a less efficient technology might have more flexibility. In this case, it could adapt more easily to an economic shock. If such is the case, late movers could theoretically have an upper hand in economically unstable contexts. In fact, with the current specification, our model has no room for early mover disadvantages, which future simulations and empirical studies might be able to tease out.

Overall, our analysis helps explain the growing advantages of first movers in volatile contexts. It does so through market logic, thereby helping to explain industry concentration and rivalry, price, and economic performance in ways that are different yet complementary to the analysis of institutional voids. Our study then complements previous analyses on the basis of non-market approaches and opens important research avenues regarding the interaction of market and non-market firm strategies. 
Recessions seem intrinsic to capitalism and affect the evolution of competition. We are hopeful that our theory and modeling will be helpful to academics and practitioners in better understanding the evolution of industry- and firm-level advantages in volatile contexts, and to be prepared to surf an eventually turbulent future.

\section{ACKNOWLEDGEMENTS}

We acknowledge financial support from Fondecyt (grant N1160048) and Núcleo Milenio Research Center in Entrepreneurial Strategy Under Uncertainty (NS130028).

\section{REFERENCES}

Agarwal, R., Sarkar, M. B., \& Echambadi, R. (2002). The conditioning effect of time on firm survival: An industry life cycle approach. Academy of Management Journal, 45(5), 971-994.

Ayyagari, M., Demirgüç-Kunt, A., \& Maksimovic, V. (2011). Do Phoenix miracles exist? Firm-level evidence from financial crises. World Bank Policy Research Working Paper Series 5799, September.

Baum, J. (1995). The changing basis of competition in organizational populations: The Manhattan hotel industry, 1898-1990. Social Forces, 74(1), 177-204. doi:10.1093/sf/74.1.177

Burns, A. F., \& Mitchell, W. C. (1946). Measuring business cycles. New York, USA: NBER Books.

Calvo, G. A., \& Mendoza, E. G. (1996). Mexico's balance-of-payments crisis: A chronicle of death foretold. Journal of International Economics, 41(3-4), 235-264. doi:10.1016/Soo22-1996(96)01436-5

Calvo, G. A., Izquierdo, A., \& Talvi, E. (2006). Sudden stops and phoenix miracles in emerging markets. American Economic Review, 96(2), 405-410.

Carrera, A., Mesquita, L., Perkins, G., \& Vassolo, R. (2003). Business groups and their corporate strategies in the Argentine roller coaster of competitive and anti-competitive shocks. Academy of Management Executive, 17(3), 32-44.

Chakrabarti, A. (2014). Organizational adaptation in an economic shock: The role of growth reconfiguration. Strategic Management Journal, 36(11), 1717-1738. doi:10.1002/smj.2309.

Chakrabarti, A., Singh, K., \& Mahmood, I. (2007). Diversification and performance: Evidence from East Asian firms. Strategic Management Journal, 28(2), 101-120. doi:10.1002/smj.572

Chakrabarti, A., Vidal, E., \& Mitchell, W. (2011). Business transformation in heterogeneous environments: The impact of market development and firm strength on retrenchment and growth reconfiguration. Global Strategy Journal, 1(1-2), 6-26. doi:10.1002/gsj.3

Claessens, S., Kose, M. A., \& Terrones, M. E. (2009). What happens during recessions, crunches and busts? Economic Policy. 24(60), 653-700. doi:10.1111/j.1468-0327.2009.00231.x 653-700
Claessens, S., Kose, M. A., \& Terrones, M. E. (2010). The global financial crisis: How similar? How different? How costly? Journal of Asian Economics, 21(3), 247-264. doi:10.1016/j.asiec0.2010.02.002

Cohen, K. J., \& Cyert, R. M. (1965). Simulation of organizational behavior. In J. G. March (Ed.), Handbook of Organizations. Chicago, USA: Rand McNally.

Davis, J. P., Eisenhardt, K. M., \& Bingham, C. B. (2007). Developing theory through simulation methods. Academy of Management Review, 32(2), 480-499. doi:10.5465/AMR.2007.24351453

Dobbs, R. F., Karakolev, T., \& Malige, F. (2001). Learning to love recessions. The McKinsey Quarterly, (2). Retrieved from http://www. mckinsey.com/

Dobrev, S. D., \& Carroll, G. R. (2003). Size (and competition) among organizations: Modeling scale-based selection among automobile producers in four major countries, 1885-1981. Strategic Management Journal, 24(6), 541-558. doi:10.1002/smj.317

García-Sánchez, J., Mesquita, L. F., \& Vassolo, R. S. (2014). What doesn’t kill you makes you stronger: The evolution of competition and entryorder advantages in economically turbulent contexts. Strategic Management Journal, 35(13), 1972-1992. doi:10.1002/smj.2189

Ghemawat, P. (1993). The risk of not investing in a recession. Sloan Management Review, 34, 51-51. Retrieved from http://sloanreview. mit.edu/

Greer, C. R., \& Ireland, T. C. (1992). Organizational and financial correlates of a "contrarian" human resource investment strategy. Academy of Management Journal, 35(5), 956-984.

Harrison, R. J., Lin, Z., Carroll, G. R., \& Carley, K. M. (2007). Simulation modeling in organizational and management research. Academy of Management Review, 32(4), 1229-1245. doi:10.5465/ AMR.2007.26586485

Isobe, T., Makino, S., \& Montgomery, D. B. (2000). Resource commitment, entry timing, and market performance of foreign direct investments in emerging economies: The case of Japanese international joint ventures in China. Academy of Management Journal, 43(3), 468-484.

Josefy, M., Kuban, S., Ireland, R. D., \& Hitt, M. (2015). All things great and small: Organizational size, boundaries of the firm, and a changing environment. Academy of Management Annals, 9(1), 715-802. doi:10 $.1080 / 19416520.2015 .1027086$

Klepper, S., \& Graddy, E. (1990). The evolution of new industries and the determinants of market structure. RAND Journal of Economics, 21(1), $27-44$.

Klepper, S. (1997). Industry life cycles. Industrial and Corporate Change, 6(1), 145-181. doi:10.1093/icc/6.1.145

Lieberman, M., \& Montgomery, D. (1988). First-mover advantages. Strategic Management Journal, 9(S1), 41-58. doi:10.1002/ smj.4250090706

Lieberman, M., \& Montgomery, D. (1998). First-mover (dis)advantages: retrospective and link with resource-based view. Strategic Management Journal, 19(12), 1111-1125.

Mascarenhas, B. (1992). Order of entry and performance in international markets. Strategic Management Journal, 13(7), 499-510. doi:10.1002/ smj.4250130703

Mascarenhas, B. (1997). The order and size of entry into international markets. Journal of Business Venturing, 12(4), 287-299. doi:10.1016/ So883-9026(96)00086-9 
Mascarenhas, B., \& Aaker, D. A. (1989). Strategy over the business cycle. Strategic Management Journal, 10(3), 199-210. doi:10.1002/ smj.4250100302

Mendoza, E. G. (2006). Lessons from debt-deflation theory of sudden stops. American Economic Review, 96(2), 411-416.

Miller, K. D., Zhao, M., \& Calantone, R. J. (2006). Adding interpersonal learning and tacit knowledge to March's exploration-exploitation model. Academy of Management Journal, 49(4), 709-722.

Pearce, J. A., \& Michael, S. C. (2006). Strategies to prevent economic recessions from causing business failure. Business Horizons, 49(3), 201-209. doi:10.1016/j.bushor.2005.08.008

Porter, M. E. (1985). Competitive advantage. New York, USA: Free Press

Porter, M. E. (1986). Changing patterns of international competition. California Management Review, 28(2), 9-40.
Siggelkow, N., \& Rivkin, J. W. (2006). When exploration backfires: Unintended consequences of multilevel organizational search. Academy of Management Journal, 49(4), 779-795. doi:10.5465/ AMJ.2006.22083053

Suarez, F., \& Lanzolla, G. (2007). The role of environmental dynamics in building a first mover advantage theory. Academy of Management Review, 32(2), 377-392. doi:10.5465/AMR.2007.24349587

Wan, W. P., \& Yiu, D. W. (2009). From crisis to opportunity: Environmental jolt, corporate acquisitions, and firm performance. Strategic Management Journal, 30(7), 791-801. doi:10.1002/smj.744

Winter, S. G. (1984). Schumpeterian competition in alternative technological regimes. Journal of Economic Behavior and Organization, 5(3-4), 287-320. doi:10.1016/0167-2681(84)90004-0 